\title{
Pengaruh Penerapan Adaptasi Kebiasaan Hidup Baru bagi Warga Masyarakat di Masa Pandemi COVID-19
}

\section{Najicha Fatma Ulfatun*1, Ayu Lestari ${ }^{2}$, Milareya Heruka Ahmad ${ }^{3}$, Azzahra Dyna ${ }^{4}$, Khairunnisa Dhia Alifah ${ }^{5}$}

\author{
${ }^{1}$ Ilmu Hukum, Fakultas Hukum, Universitas Sebelas Maret, Indonesia \\ ${ }^{2}$ Agroteknologi, Fakultas Pertanian, Universitas Sebelas Maret, Indonesia \\ ${ }^{3}$ Agribisnis, Fakultas Pertanian, Universitas Sebelas Maret, Indonesia \\ ${ }^{4}$ Pendidikan Fisika, Fakultas Keguruan dan Ilmu Pendidikan, Universitas Sebelas Maret, Indonesia \\ ${ }^{5}$ Peternakan, Fakultas Pertanian, Universitas Sebelas Maret, Indonesia \\ Email: ${ }^{1}$ fatmanajicha_law@staff.uns.ac.id, ${ }^{2}$ ayu_lestari017@ @tudent.uns.ac.id, \\ 3herukaahmadmilareva@student.uns.ac.id, ${ }^{4}$ dynaazzahra178@student.uns.ac.id, \\ 5dhialifahk@student.uns.ac.id
}

\begin{abstract}
Abstrak
Pandemi COVID-19 saat ini telah menjadi masalah Kesehatan global yang telah telah melanda lebih dari 200 negara di dunia, termasuk Indonesia. Pada saat ini pemerintah sedang melaksanakan peraturan pemerintah yang dimana membatasi kegiatan masyarakat selama pandemi COVID-19. Adanya pelaksanaan peraturan ini dapat memberikan dampak social yang sangat besar untuk kehidupan masyarakat secara material maupun immaterial. Pemerintah saat ini melakukan PPKM (Pemberlakuan Pergerakan Kegiatan Masyarakat yang bertujuan guna mengurangi persentase penularan COVID-19 dan dapat dikendalikan. Adanya PPKM saat ini membuat masyarakat untuk beradaptasi dengan kebiasaan baru, diantaranya tidak berkerumun di tempat umum, dilarangnya berpergian ke luar kota, dan masih banyak lagi. Hal ini harus diterapkan supaya penularan COVID-19 ini tidak menyebar. Namun, fakta di lapangan masih banyak masyarakat yang belum memahami pengetahuan mengenai adaptasi kebiasaan baru pada masa pandemi COVID-19. Pelaksanaan kegiatan pengabdian kepada masyarakat in menggunakan metode deskriptif yang memiliki tujuan memberikan sosialisasi mengenai adaptasi kebiasaan baru pada masa pandemi COVID-19 sehingga dapat menyampaikan informasi yang benar mengenai kebiasaan baru yang seharusnya dilakukan. Tujuan dilaksanakannya penelitian ini adalah untuk memberikan pemahaman yang benar terkait masalah pandemi COVID-19, sehingga mendapatkan pengetahuan untuk secara mandiri melakukan tindakan preventif dan promotif guna mencegah penularan penyakit, serta mengurangi kecemasan berlebihan akibat informasi tidak benar. Metode yang digunakan dalam penelitian ini adalah metode penelitian kualitatif yang mana analisis datanya menggunakan analisis data induktif. Penyusunan adaptasi kebiasaan baru ini dilakukan sebagai upaya untuk memulihkan kembali, mendukung berlangsungnya ekonomi dan aktivitas sektor yang sempat terhambat akibat adanya pandemi ini dengan tetap menjaga upaya pencegahan dan pengendalian penularan COVID-19. Sebanyak 82,3\% masyarakat di Jawa-Bali menyatakan patuh dalam menghindari kerumunan. Namun, sebanyak 90,5\% masyarakat Jawa-Bali masih sering memakai satu masker dan belum menerapkan pemakaian masker double (kain, dan masker medis).
\end{abstract}

Kata kunci: Adaptasi Kebiasaan Baru, COVID-19, PPKM

\begin{abstract}
The current COVID-19 pandemic has become a global health problem that has hit more than 200 countries in the world, including Indonesia. At this time the government is implementing government regulations which limit community activities during the COVID-19 pandemic. The implementation of this regulation can have a very large social impact on people's lives both materially and immaterially. The government is currently conducting PPKM (Enforcement of the Movement of Community Activities which aims to reduce the percentage of COVID-19 transmission and can be controlled. The current PPKM makes people adapt to new habits, including not crowding in public places, prohibiting traveling outside the city, and many more again. This must be implemented so that the transmission of COVID-19 does not spread. However, the fact in the field is that there are still many people who do not understand the knowledge about adapting new habits during the COVID-19 pandemic. The implementation of this community service activity uses a descriptive method that has a purpose provide
\end{abstract}


socialization regarding the adaptation of new habits during the COVID-19 pandemic so that they can convey correct information about new habits that should be carried out. The purpose of this research is to provide a correct understanding of the problem of the COVID-19 pandemic, so as to gain knowledge to independently take preventive and promotive actions to prevent disease transmission, as well as reduce excessive anxiety due to incorrect information. The method used in this study is a qualitative research method in which the data analysis uses inductive data analysis. The preparation of this new habit adaptation was carried out as an effort to restore, support the ongoing economy and sector activities that had been hampered due to this pandemic while maintaining efforts to prevent and control the transmission of COVID-19. As many as $82.3 \%$ of the people in Java-Bali said they were obedient in avoiding crowds. However, as many as $90.5 \%$ of the people of Java-Bali still often wear one mask and have not applied the use of double masks (cloth and medical masks).

Keywords: COVID-19, New Normal, PPKM

\section{PENDAHULUAN}

Pada masa pandemi saat ini, Pemberlakuan Pergerakan Kegiatan Masyarakat (PPKM) menjadi salah satu cara pemerintah untuk membatasi dan mengurangi pergerakan warga agar virus corona ini tidak menyebar. Namun dengan terbatasnya pergerakan warga saat ini tentu menimbulkan dampak yang kurang baik bagi masyarakat terutama pada segi ekonominya. Permasalahan jumlah penghasilan yang terbatas bagi masyarakat tentu menjadi masalah tersendiri yang perlu diatasi dan dipecahkan oleh kepala daerah atau pejabat negeri ini. Pada saat ini masih banyak masyarakat yang belum mengetahui bagaimana cara agar dapat melakukan aktivitas yang terbatas ini namun masih aman dari penularan virus.

Virus corona atau yang dikenal sebagai Severe Acute Respiratory Syndrome Coronavirus 2 (SARS$\mathrm{CoV}-2$ ) merupakan virus yang menginfeksi sistem pernapasan orang yang terjangkit (Wahyudin et al, 2021). Virus corona ini bisa menyebabkan hal yang fatal terutama bagi mereka yang mengalami gangguan pernapasan sebelumnya. Virus corona ini pertama kali ditemukan di Kota Wuhan, China yang menyebar cepat ke seluruh dunia (Wahidah et al., 2020). Upaya pemerintah dalam mengurangi kasus penyebaran Virus corona ini dengan melakukan berbagai kebijakan salah satunya dengan sistem work from home, dimana kegiatan yang dilakukan oleh masyarakat dalam bekerja, belajar dan beribadah bisa dari rumah saja sehingga dapat menurunkan tingkat interaksi sosial di tempat umum dan dapat menurunkan potensi penyebaran COVID-19 (Herdiana, 2020).

Peraturan pemerintah dalam membatasi aktivitas kegiatan masyarakat selama pandemi COVID-19 saat ini memberikan dampak yang besar bagi sosial kehidupan masyarakat pada umumnya. Pemerintah memberlakukan Pemberlakuan Pergerakan Kegiatan Masyarakat (PPKM) mempunyai tujuan yaitu agar penularan COVID-19 dapat dikendalikan dan kedepannya virus ini akan hilang, walaupun sebelumnya sudah ada kebijakan yang namanya PSBB. PPKM saat ini membuat masyarakat untuk dapat beradaptasi dengan kebiasaan baru, seperti halnya dengan makan ditempat dengan jumlah waktu yang dibatasi, tidak berkerumun di tempat umum, dilarangnya berpergian ke luar kota, dan lain-lain. Hal ini harus diterapkan agar penularan COVID-19 ini tidak terus menyebar. Namun, faktanya masih banyak masyarakat yang masih perlu untuk diberikan informasi dan edukasi mengenai adaptasi kebijakan baru ini di masa pandemi COVID-19 ini. Penyusunan adaptasi kebiasaan baru ini dilakukan sebagai upaya untuk memulihkan kembali, mendukung berlangsungnya ekonomi dan aktivitas sektor yang sempat terhambat akibat adanya pandemi ini dengan tetap menjaga upaya pencegahan dan pengendalian penularan COVID-19 (Br Sembring \& Lim, 2020). Adaptasi kebiasaan baru berhubungan dengan pola hidup sehat di masyarakat. Perilaku Hidup Bersih dan Sehat (PHBS) pada dasarnya merupakan salah cerminan pola hidup keluarga yang senantiasa memperhatikan dan menjaga kesehatan seluruh anggota keluarga. Perilaku tersebut dilakukan atas kesadaran masing-masing sehingga anggota keluarga atau keluarga dapat menolong dirinya sendiri dibidang kesehatan serta berperan aktif dalam kegiatan kesehatan di masyarakat (Proverawati \& Rahmawati, 2012). Oleh sebab itu, sudah saatnya semua pihak bekerja sama sehingga kehidupan normal kembali dapat terwujud. Tujuan dilaksanakannya penelitian ini adalah untuk memberikan pemahaman yang benar terkait masalah pandemi COVID-19, sehingga mendapatkan 
pengetahuan untuk secara mandiri melakukan tindakan preventif dan promotif guna mencegah penularan penyakit, serta mengurangi kecemasan berlebihan akibat informasi tidak benar.

\section{METODE PENELITIAN}

Penelitian ini menggunakan metode penelitian kualitatif. Patton dan Cochran (2002) menyatakan bahwa jenis penelitian ini ditandai melalui tujuannya, yang terkait dengan membahas dan memahami beberapa aspek kehidupan sosial, dan sebagai data untuk analisis, metodenya yang menghasilkan kalimat, bukan angka. Penelitian kualitatif adalah pemahaman tentang fenomena sosial berdasarkan sudut pandang partisipan. Selain itu, metode penelitian deskriptif kualitatif adalah metode penelitian yang bertujuan untuk menggambarkan hal-hal yang menjadi objek penelitian dalam perjudian, berikut definisi deskriptif metode penelitian Djajasudarma (2006) metode penelitian deskriptif-kualitatif bertujuan untuk membuat deskripsi atau sistem, dan data, properti, dan hubungan yang akurat dan fenomena yang dipelajari. Metode penelitian deskriptif yang telah dijelaskan di atas, umumnya memiliki model penelitian induktif, dengan urutan
a. Mengumpulkan informasi,
b. Menanya pertanyaan,
c. Membangun kategori
d. Mencari pola (teori), dan
e. Membangun teori atau membandingkan pola dengan teori lain.

Dalam tulisan ini, objek data penelitian adalah masyarakat terdampak COVID-19, yang: terletak di Jawa-Bali. Data diperoleh dengan menggunakan metode analisis data Induktif. Metode analisis induktif ini digunakan untuk menilai dan menganalisis data yang telah difokuskan tentang dampak penerapan kebiaasan hidup baru bagi warga masyarakat di masa COVID-19. Analisis induktif ini peneliti gunakan dengan cara menganalisis hal-hal yang khusus untuk selanjutnya ditarik kesimpulan yang objektif.

\section{HASIL DAN PEMBAHASAN}

Saat ini pemerintah mulai menerapkan kebijakan Adaptasi Kebiasaan Baru atau bisa juga disebut New Normal, tujuannya adalah untuk memulihkan perekonomian di tengah pandemi COVID-19 yang saat ini sedang terjadi. Maka sangat penting bagi kita semua untuk mengetahui apa artinya dalam kehidupan sehari-hari. Prinsip new normal adalah bisa menyesuaikan dengan pola hidup (Ramadhana, 2020). Transformasi ini adalah untuk menata kehidupan dan perilaku baru, ketika pandemi, yang kemudian akan dibawa terus ke depannya sampai ditemukannya vaksin untuk COVID-19 ini. (Adisasmita, 2020, Kemenkes, 2020). New normal ditujukan agar negara tetap bisa menjalankan fungsinya sesuai konstitusi. Pemerintah dapat menjalankan fungsinya mengurusi rakyat apabila ada pemasukan kas negara yang bersumber dari pajak dan penerimaan negara lainnya. Jika kegiatan perekomian berhenti, maka negara tidak memiliki pemasukan dan berimbas pada rakyat juga.

Kini, protokol new normal telah dirilis oleh Kementerian Kesehatan pada Senin, 25 Mei 2020 berdasarkan Keputusan Menteri Kesehatan Nomor HK.01.07/MENKES/328/2020 tentang Panduan Pencegahan dan Pengendalian COVID-19 di Tempat Kerja Perkantoran dan Industri dalam Mendukung Keberlangsungan Usaha pada Situasi Pandemi. Adapun protokol kesehatan yang dimaksud di antaranya menjaga kebersihan tangan, menggunakan masker ketika keluar rumah, menjaga jarak, serta menjaga kesehatan dengan asupan makanan dan berolahraga (Mulyaningsih et al, 2020). Protokol kesehatan juga mengatur tata cara berkumpul di luar rumah, makan di restoran hingga beribadah.

Kebiaasan baru yang akan dilakukan memasuki kondisi "new normal" (Santoso et al, 2021).

a. Kebiasaan mencuci tangan dengan sabun atau handsanitizer sesuai dengan tata cara mencuci tangan yang benar.

b. Selalu menggunakan masker apabila beraktivitas keluar rumah. Masker kain digunakan untuk orang sehat, masker medis (bedah) digunakan untuk mereka yang batuk, flu, dan radang tenggorokan, masker N95 digunakan untuk tenaga medis dan kontak langsung dengan pasien COVID-19.

c. Menghindari kerumunan massa/berkumpul di tempat keramaian untuk mencegah penyebaran. 
Pada saat ini, banyak masyarakat di lingkungan kita yang patuh terhadap seberapa bahaya COVID19, masyarakat telah banyak mengindahkan anjuran pemerintah untuk menggunakan handsanitizer serta masker ketika keluar dari ruang karantina sendiri yaitu rumah. Pada setiap tempat-tempat makan juga telah melakukan protokol kesehatan yaitu memberikan tanda jarak pemesanan setiap konsumen, memberi jarak pada tempat makan serta para karyawan yang menggunakan masker dan alat protokol kesehatan.

Mengapa dianjurkan untuk selalu gunakan masker saat keluar rumah? Karena kita mungkin membawa virus tapi tidak memiliki gejala atau hanya gejala ringan, sehingga bisa menularkan ke orang lain. Tapi masker harus dipakai dengan benar. Pastikan masker menutupi hidung, mulut, dan dagu dan hanya dipakai satu kali. Masker kain dipakai ulang setelah dicuci dengan deterjen. tetapi masker medis harus dibuang begitu sampai di rumah. Meskipun kebijakan new normal telah diberlakukan oleh pemerintah, masih banyak masyarakat yang tidak mematuhi kebijakan ini. Banyak yang masih tidak peduli untuk melakukan protokol kesehatan di kegiatannya sehari-hari. Bahkan mereka masih kurang mengetahui kebijakan new normal ini sehingga mereka masih banyak yang menyepelekan kebijakan tersebut. Tempat umum seperti pasar, tempat wisata, dan lainnya ramai dikunjungi dan banyak yang tidak menjaga jarak antara satu dengan yang lain.

Ada beberapa faktor yang menyebabkan masyarakat kurang memahami terkait new normal dan pentingnya meningkatkan protokol kesehatan (Rosidi et al, 2020)

a. Kurang patuhnya masyarakat terhadap himbauan dari pemerintah tentang bahaya COVID-19

b. Kurangnya minat baca dari masyarakat perihal pencegahan COVID-19

c. Kurangnya kesadaran pribadi dari masyarakat itu sendiri betapa pentingnya edukasi pencegahan dan penanganan COVID-19

d. Kurangnya sosialisasi dan edukasi yang didapat masyarakat karena mereka hanya mendengarkan berita di televisi

Menurut hasil survei oleh Badan Pusat Statistik protokol kesehatan yang paling jarang diterapkan oleh masyarakat khususnya di wilayah Jawa-Bali adalah menggunakan masker dua lapis. Hanya 61,4\% responden di wilayah tersebut yang sering mengenakan masker dua lapis untuk mencegah virus corona COVID-19. Sebanyak 23,9\% responden masih jarang menggunakan masker dua lapis. Sebanyak 14,7\% responden pun mengaku abai mengenakan masker dua lapis. Masyarakat Jawa-Bali yang patuh menjaga jarak tercatat sebanyak $71,1 \%$. Sebanyak $24,2 \%$ responden menyatakan jarang menjaga jarak. Sedangkan, 4,7\% mengaku jarang sekali menjaga jarak. Kemudian, ada 78,6\% masyarakat Jawa-Bali yang rajin mencuci tangan dengan sabun. Sebanyak $17,6 \%$ responden menyatakan hanya kadangkadang mencuci tangan dengan sabun. Sementara, sebanyak 3,8\% mengaku abai menerapkan protokol kesehatan itu.

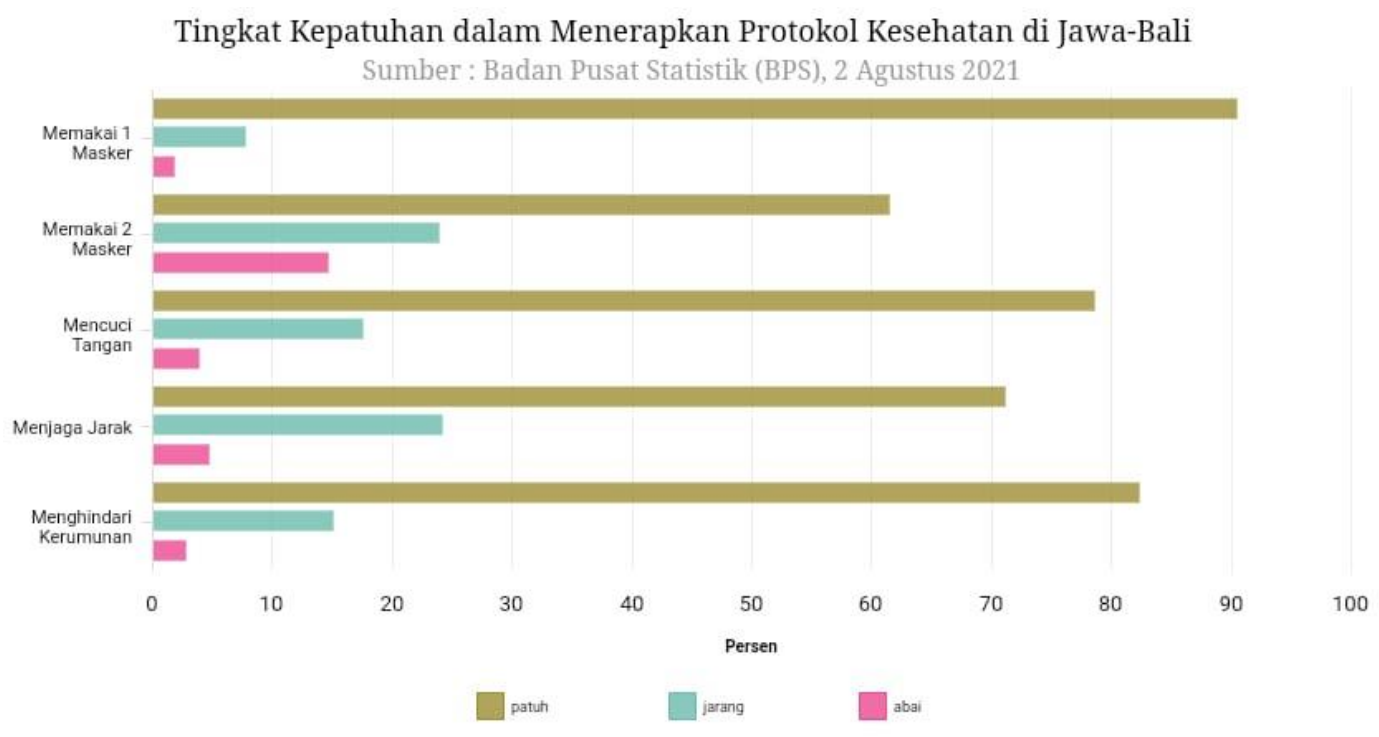

Gambar 1. Tingkat Kepatuhan Penerapan Protokol Kesehatan 
Sebanyak 82,3\% masyarakat di Jawa-Bali menyatakan patuh dalam menghindari kerumunan. Sebanyak $15 \%$ responden menyatakan jarang menghindari kerumunan. Sedangkan, hanya 2,7\% responden yang abai menghindari kerumunan. Adapun, masyarakat Jawa-Bali yang sering memakai satu masker sebanyak 90,5\%. Jumlah responden yang jarang menerapkan protokol kesehatan tersebut sebanyak $7,7 \%$. Sementara, cuma $1,8 \%$ responden yang abai menggunakan satu masker. Sosialisasi adaptasi kebiasaan baru di masyarakat dapat dilakukan secara daring (online) untuk menyadarkan masyarakat agar tetap mematuhi protokol kesehatan di era new normal ini untuk memutuskan rantai penyebaran COVID-19. Salah satu bentuk sosialisasi yang dapat dilakukan adalah dengan membuat poster yang disebarluaskan melalui media sosial seperti grup WhatsApp dan Instagram. Melalu pembuatan poster yang mudah dipahami dan menarik, masyarakat akan lebih tertarik untuk sekadar membaca terkait protokol kesehatan di era new normal.

\section{KESIMPULAN}

Penyusunan adaptasi kebiasaan baru ini dilakukan sebagai upaya untuk memulihkan kembali, mendukung berlangsungnya ekonomi dan aktivitas sektor yang sempat terhambat akibat adanya pandemi ini dengan tetap menjaga upaya pencegahan dan pengendalian penularan COVID-19. Sebanyak $82,3 \%$ masyarakat di Jawa-Bali menyatakan patuh dalam menghindari kerumunan. Namun, sebanyak 90,5\% masyarakat Jawa-Bali masih sering memakai satu masker dan belum menerapkan pemakaian masker double (kain, dan masker medis).

Oleh sebab itu, perlu adanya sosialisasi lebih lanjut mengenai adaptasi kebiasaan baru di masyarakat yang dapat dilakukan secara daring (online) untuk menyadarkan masyarakat agar tetap mematuhi protokol kesehatan di era new normal ini untuk memutuskan rantai penyebaran COVID-19.

\section{DAFTAR PUSTAKA}

Adisasmita, W. (2020). Mengenal Konsep New Normal. Indonesia.go.id https://indonesia.go.id/ragam/komoditas/ekonomi/mengenal-konsep-new-normal

Br Sembring, E., \& Peter Lim. (2020). Edukasi Adaptasi Kebiasaan Baru Di Lingkungan Kampus (Studi Kasus : Motion Graphic Penggunaan Lift). Journal Teknik Informatika 3(2), 61-76.

Herdiana, D. (2020). Penanggulangan COVID-19 Tingkat Lokal Melalui Kebijakan Adaptasi Kebiasaan Baru (AKB) Di Provinsi Jawa Barat. Journal of Governance Innovation 2(2), 131-56.

Keputusan Menteri. (2020). Keputusan Menteri Desa, Pembangunan Daerah Tertinggal, dan Transmigrasi Republik Indonesia Nomor 63 Tahun 2020 Tentang Protokol Normal Baru Desa. Jakarta

Mulyaningsih S., Amalia L., Hernawan H., et al. (2020). Edukasi adaptasi kebiasaan baru pada masa Pandemi COVID-19. Jurnal PEKEMAS 3(1), 1-4.

Proverawati, Atikah. (2012). Perilaku Hidup Bersih Dan Sehat (PHBS). Yogyakarta: Nuha Medika

Ramadhana M. R. (2020). Mempersiapkan ketahanan keluarga selama adaptasi kebiasaan baru di masa Pandemi COVID-19. Jurnal Kependudukan Indonesia 61-68.

Rosidi, A., \& ROSIDI, E. N. (2020). Penerapan new normal (kenormalan baru) dalam penanganan COVID-19 sebagai pandemi dalam hukum positif. Journal Ilmiah Rinjani: Media Informasi Ilmiah Universitas Gunung Rinjani, 8(2), 193-197.

Santoso M. B., Zalnudiin M., Asiah D. S. (2021). Menumbuk kesadaran masyarakat melalui sosialisasi kebiasaan hidup baru di Masa Pandemi COVID-19. Jurnal Pengabdian dan Penelitian Kepada Masyarakat (JPPM) 2(1), 80-87.

Wahidah, I., Andi Septiadi, M., Choerul Adli Rafqie, M., Salsabila Hartono, N. F., Athallah, R. (2020). Pandemik COVID-19: Analisis Perencanaan Pemerintah dan Masyarakat dalam Berbagai Upaya Pencegahan. Jurnal Manajemen dan Organisasi (JMO) 11(3), 179-188.

Wahyudin, Yani A., Junaidi A. (2021). Sosialisasi adaptasi kebiasaan baru di masa Pandemi COVID19 untuk ibu-ibu PKK Kelurahan Gembor, Tangerang. Jurnal Pengabdian Masyarakat 1(1), 8-12. 


\section{Halaman Ini Dikosongkan}

